\title{
The Physical and Biochemical Characteristics of Resistance in Different Rice Varieties and Initial Moisture Content for Their Susceptibility to Rhyzopertha dominica F. (Coleoptera: Bostrichidae)
}

\author{
Ludji Pantja ASTUTI*, Gatot MUDJIONO, \\ Siti Ch. RASMINAH and Bambang Tri RAHARDJO
}

Faculty of Agriculture, University of Brawijaya, Malang, Indonesia

('Corresponding author's email: ludji_pa@ub.ac.id)

Received: 11 April 2019, Revised: 19 January 2020, Accepted: 14 February 2020

\begin{abstract}
Rhyzopertha dominica reduces the weight of rice production at approximately $40 \%$. This study aimed to investigate the physical and biochemical characteristics of resistance in different rice varieties at different initial moisture content to their susceptibility against $R$. dominica. The study consisted of 2 experiments: (i) free-choice, and (ii) no-choice tests. These experiments were conducted by combining 6 rice varieties $\left(\mathrm{V}_{\mathrm{i}}\right)$ : IR-64, Ciherang, Membramo, Cibogo, Sembada, and, Intani-2, and 4 levels of initial moisture content $\left(\mathrm{K}_{\mathrm{i}}\right): 10,12,14$, and $16 \%$. The observed variables for the free-choice test were the number of adult insects (male and female) present, the number of females present, and the percentage of weight loss. The observed variables for the no-choice test were the number of eggs, larvae, F1 progeny emerged, and the median developmental time of $R$. dominica. Results of the free-choice test revealed that the highest total number of adult insects present, the female insects present, and the percentage of weight loss appeared in the Intani-2 variety at $16 \%$ initial moisture content, while the lowest of these 3 variables appeared in the Membramo variety at $10 \%$ initial moisture content. The no-choice test revealed that the rice varieties became more susceptible with the increase of the initial moisture content. The susceptibility of rice was affected by hardness, ash content, and phenol content. Rice hardness level were caused by the level of initial moisture content. However, the chemical characteristics of the rice were not affected by the level of initial moisture content.
\end{abstract}

Keywords: Preference parameters, Resistance characteristic, $R$. dominica, Susceptibility index

\section{Introduction}

Stored product pests are a biotic factor that cause product losses, especially in grain. Because of infestation, the estimated loss of stored products is approximately $20 \%$ [1]. Infestation of Rhyzopertha dominica reduces the weight of brown rice production at approximately $40 \%$ [2]. The larvae and adults of $R$. dominica spend most of their lifetime inside the kernel, feeding on both germ and endosperm that directly causes damage and changes in the physicochemical properties of the grain $[3,4]$. A survey in Indonesia revealed that the insects which are categorized as pests in rice are Sitophilus oryzae, $R$. dominica, Tribolium castaneum, Oryzaephilus surinamensis, and Sitotroga cerealella [5]. Astuti [6] reported during March and April 2010 in the warehouse of Bulog, regional sub-division Malang, East Java, indicated that the population of $R$. dominica was more dominant than other insects. The causative factors of these increase are unknown. The various conditions of rice, in terms of variety, water content, and physical and chemical characteristics, allow the opportunity for pests to infest stored rice. The research results of Astuti et al. [7] determined that several rice varieties have different physical and biochemical characteristics. Based on Astuti et al. [7], these varieties have different levels of 
http://wjst.wu.ac.th

susceptibility to $R$. dominica. Furthermore, this susceptibility to $R$. dominica range from highly susceptible to resistant [7]. Astuti et al. [8] stated that the temperature and relative humidity of the warehouse significantly affect the development of $R$. dominica. The research results of Kumawat [9] also showed that the increase in temperature causes shorter periods of the egg, larvae, and pupae of $R$. dominica in wheat. Speigh et al. [10] and Sousa et al. [11] stated that, besides temperature and humidity, insect abundance depends on the availability and the quality of feed. Lower initial moisture content in grain can lengthen the larval period and reduce insect survival [12]. Based on the previous research, pest management of stored rice can be done by modifying the abiotic factor components in the warehouse, for example, by setting the initial moisture content of stored grain.

\section{Materials and methods}

This study consisted of 2 experiments: (i) the free-choice and (ii) no-choice tests. The free-choice test was conducted by combining 6 rice varieties $\left(\mathrm{V}_{\mathrm{i}}\right)$ and 4 levels of the initial moisture content of rice $\left(\mathrm{K}_{\mathrm{j}}\right)$. Rice varieties were: IR-64 $\left(\mathrm{V}_{1}\right)$, Ciherang $\left(\mathrm{V}_{2}\right)$, Membramo $\left(\mathrm{V}_{3}\right)$, Cibogo $\left(\mathrm{V}_{4}\right)$, Sembada $\left(\mathrm{V}_{5}\right)$, and Intani-2 $\left(\mathrm{V}_{6}\right)$. The initial moisture contents were: $10 \%\left(\mathrm{~K}_{1}\right), 12 \%\left(\mathrm{~K}_{2}\right), 14 \%\left(\mathrm{~K}_{3}\right)$, and $16 \%\left(\mathrm{~K}_{4}\right)$. The experiment was arranged by randomized complete block design and repeated 5 times.

The experiment was carried out by placing $30 \mathrm{~g}$ of each treatment into each chamber of a preference cage (Figure 1); then, 360 mating pairs of $R$. dominica adults aged between 1 and 2 weeks were placed into the preference cage. The infestation was done by releasing the insects in the center of the preference cage to provide an equal chance for each rice to be chosen as a host by $R$. dominica. Adults of $R$. dominica were removed from the preference cage on 1 week after infestation. Furthermore, infested rice by $R$. dominica eggs in each treatment combination was transferred into glass tube $(7 \mathrm{~cm}$ tall, $\varnothing 4.5 \mathrm{~cm})$ and wrapped in gauze material until F1 progeny emerged.

The observed variables were the number of adult insects (male and female) present, the number of female adult insects present, and the percentage of weight loss. The calculation of the number of adult insects present and the number of female adult insects present was carried out on 7 days after infestation. The percentage of weight loss was observed at the end of the experiment.

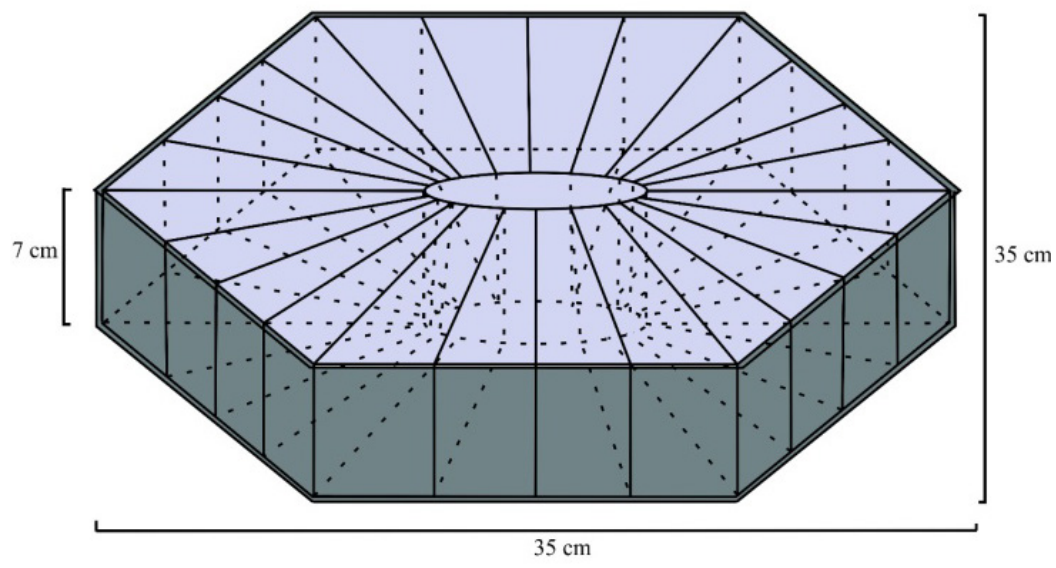

Figure 1 Chambers of preference cage.

The second experiment used no-choice test; 6 rice varieties were combined $\left(\mathrm{V}_{\mathrm{i}}\right)$ with 4 levels of initial moisture content of rice $\left(\mathrm{K}_{\mathrm{j}}\right)$ as in the first experiment. The no-choice test experiment was carried out by filling each glass jar $(7 \mathrm{~cm}$ tall, $\varnothing 4.5 \mathrm{~cm})$ with $30 \mathrm{~g}$ of each rice variety, according to the 
http://wjst.wu.ac.th

treatment. Each jar was infested with 15 mating pairs of adult $R$. dominica, 2 to 3 weeks old, and was wrapped in gauze. Sterilization of rice, water content measurement of rice, and $R$. dominica that was used in this experiment were the same as in the first experiment. This experiment used complete randomized design and was repeated 5 times. Adult insects of $R$. dominica were removed after 1 week of infestation. Furthermore, infested rice with eggs was incubated until F1 progeny emerged.

The observed variables were the number of eggs, larvae, F1 progeny emerged, and median developmental time of $R$. dominica. The number of adults was calculated from first emergence until all the F1 progeny emerged. The susceptibility index was calculated using Dobie and Kilminister [13], while the susceptibility category was based on the Dobie method [14].

The recording data were subject to analysis of variance (ANOVA) and means were compared using Duncans Multiple Range Test at $5 \%$ level of significance. Regression and correlation analysis on the various variables of $R$. dominica, initial moisture content, chemical content, and hardness level of rice variety was computed [15].

\section{Results and Discussion}

The results of the free-choice test experiment showed that the number of adult insects (male and female) present, the number of female adult insects present, and the percentage of weight loss showed a significantly different interaction (Table 1).

It can be seen from Table 1 the increasing of initial moisture content in each variety from $10 \%$ to $16 \%$ could increase the number of adult insects present and the number of female adult insects present by different patterns. This showed that the number of adult insects present and number of female adult insects present in 6 rice varieties were in line with the increase in initial moisture content. The lowest number of adult insects present and number of female adult insects present at $10 \%$ of initial moisture content was recorded in the Membramo variety, followed by the Ciherang, IR-64, Cibogo, Sembada, and Intani-2 varieties. It also appeared, in other levels of initial moisture content, that the lowest number of adult insects present and number of female adult insect presents were recorded in the Membramo variety, followed by the Ciherang, IR 64, Cibogo, Sembada, and Intani-2 varieties. The lowest total number of adult insects present was in Membramo, at $10 \%$ initial moisture content (16.6 individuals), and the highest was in Intani-2, at $16 \%$ initial moisture content (42.2 individuals). Similarly, the lowest number of female adult insects present was in Membramo, at $10 \%$ initial moisture content (8.6 individuals), and the highest was in Intani-2, at $16 \%$ initial moisture content (22.6 individuals). Based on the response of each variety by increasing initial moisture content to the percentage of weight loss, the lowest percentage of weight loss due to $R$. dominica infestation was in the Membramo variety, at $10 \%$ initial moisture content $(0.35 \%)$, and the highest was in the Intani-2 variety, at $16 \%$ initial moisture content $(17.87 \%)$.

The no-choice test experiment showed that the interaction between varieties and initial moisture contents of rice significantly affected the number of eggs, larvae, and F1 progeny of $R$. dominica (Table 2). The results showed that the increase of initial moisture content in the same rice varieties from $10 \%$ to $16 \%$ could increase the mean number of eggs, larvae, and F1 progeny at different increasing levels.

The response of the rice varieties and the initial moisture contents to the mean number of eggs, larvae, and F1 progeny emerged showed a certain pattern, i.e., the Membramo variety was the lowest, followed by Ciherang, IR-64, Cibogo, Sembada, and Intani-2. The same pattern occurred at all initial moisture content levels, which were tested at different increasing levels. This showed that the effect of the initial moisture content on the mean number of eggs, larvae, and F1 progeny had different increasing levels. 
http://wjst.wu.ac.th

Table 1 Mean number of adult insects (male and female), number of female adult insects present $(\bar{X} \pm \mathrm{SE})$ of $R$. dominica, and percentage of weight loss $(\bar{X} \pm \mathrm{SE})$ in 6 rice varieties with different initial moisture content levels in free-choice test experiment.

\begin{tabular}{|c|c|c|c|c|c|}
\hline \multirow{3}{*}{ Varieties } & \multicolumn{5}{|c|}{ Mean number of $R$. dominica adult insects: } \\
\hline & \multirow{2}{*}{$\begin{array}{l}\text { Initial } \\
\text { moisture } \\
\text { content }\end{array}$} & \multirow{2}{*}{$\begin{array}{l}\text { Number of adult } \\
\text { insects } \\
\text { out of } 720\end{array}$} & \multirow{2}{*}{$\begin{array}{l}\text { Number of female } \\
\text { adult insects } \\
\text { out of } 360\end{array}$} & \multicolumn{2}{|c|}{ Weight loss (\%) } \\
\hline & & & & $(\%)$ & Arcsin \\
\hline \multirow[t]{4}{*}{ IR-64 } & $10 \%$ & $20.4 \pm 1.04 \mathrm{bc}$ & $10.4 \pm 0.80 \mathrm{abc}$ & $1.64 \pm 0.06$ & $7.36 \mathrm{f}$ \\
\hline & $12 \%$ & $22.0 \pm 1.05 \mathrm{c}$ & $11.2 \pm 0.93 \mathrm{c}$ & $2.01 \pm 0.05$ & $8.15 \mathrm{gh}$ \\
\hline & $14 \%$ & $27.8 \pm 0.54 \mathrm{~g}$ & $13.8 \pm 1.02 \mathrm{f}$ & $2.22 \pm 0.07$ & $8.57 \mathrm{hi}$ \\
\hline & $16 \%$ & $32.4 \pm 1.00 \mathrm{hi}$ & $16.4 \pm 1.05 \mathrm{gh}$ & $2.61 \pm 0.05$ & $9.23 \mathrm{jk}$ \\
\hline \multirow{4}{*}{ Ciherang } & $10 \%$ & $20.6 \pm 1.02 \mathrm{bc}$ & $10.6 \pm 1.00 \mathrm{~b}$ & $1.05 \pm 0.05$ & $5.88 \mathrm{~cd}$ \\
\hline & $12 \%$ & $22.6 \pm 1.11 \mathrm{~cd}$ & $11.4 \pm 0.95 \mathrm{~cd}$ & $1.21 \pm 0.06$ & $6.30 \mathrm{de}$ \\
\hline & $14 \%$ & $24.0 \pm 1.07 \mathrm{de}$ & $12.0 \pm 1.09 \mathrm{cdef}$ & $1.34 \pm 0.05$ & $6.66 \mathrm{e}$ \\
\hline & $16 \%$ & $26.8 \pm 0.65 \mathrm{f}$ & $13.2 \pm 0.96 \mathrm{def}$ & $1.88 \pm 0.04$ & $7.87 \mathrm{~g}$ \\
\hline \multirow{4}{*}{ Membramo } & $10 \%$ & $16.6 \pm 1.01 \mathrm{a}$ & $8.6 \pm 0.80 \mathrm{a}$ & $0.35 \pm 0.04$ & $3.19 \mathrm{a}$ \\
\hline & $12 \%$ & $18.0 \pm 1.18 \mathrm{ab}$ & $9.2 \pm 1.11 \mathrm{ab}$ & $0.39 \pm 0.03$ & $3.59 \mathrm{a}$ \\
\hline & $14 \%$ & $21.0 \pm 1.10 \mathrm{c}$ & $10.8 \pm 1.01 \mathrm{~b}$ & $0.51 \pm 0.05$ & $4.07 \mathrm{~b}$ \\
\hline & $16 \%$ & $24.8 \pm 1.15 \mathrm{def}$ & $12.8 \pm 1.09 \mathrm{cdef}$ & $0.59 \pm 0.03$ & $4.50 \mathrm{c}$ \\
\hline \multirow[t]{4}{*}{ Cibogo } & $10 \%$ & $22.6 \pm 1.10 \mathrm{~cd}$ & $11.8 \pm 1.05 \mathrm{cde}$ & $2.45 \pm 0.05$ & $9.02 \mathrm{ij}$ \\
\hline & $12 \%$ & $25.4 \pm 1.05$ defgh & $12.6 \pm 1.08 \mathrm{cdef}$ & $2.81 \pm 0.06$ & $9.66 \mathrm{k}$ \\
\hline & $14 \%$ & $33.2 \pm 1.01 \mathrm{hij}$ & $16.4 \pm 0.90 \mathrm{gh}$ & $3.23 \pm 0.04$ & 10.341 \\
\hline & $16 \%$ & $37.0 \pm 1.07 \mathrm{klm}$ & $18.8 \pm 0.85 \mathrm{i}$ & $3.90 \pm 0.06$ & $11.39 \mathrm{~m}$ \\
\hline \multirow[t]{4}{*}{ Sembada } & $10 \%$ & $22.8 \pm 1.04 \mathrm{~cd}$ & $11.8 \pm 1.06 \mathrm{cde}$ & $3.17 \pm 0.05$ & 10.251 \\
\hline & $12 \%$ & $26.0 \pm 1.10 \mathrm{efg}$ & $13.4 \pm 1.07 \mathrm{ef}$ & $3.62 \pm 0.06$ & $10.96 \mathrm{~m}$ \\
\hline & $14 \%$ & $31.8 \pm 1.00 \mathrm{~h}$ & $15.6 \pm 0.93 \mathrm{~g}$ & $4.88 \pm 0.07$ & $13.15 \mathrm{n}$ \\
\hline & $16 \%$ & $39.0 \pm 1.12 \mathrm{~m}$ & $20.6 \pm 0.85 \mathrm{j}$ & $7.32 \pm 0.05$ & $15.66 \mathrm{p}$ \\
\hline \multirow[t]{4}{*}{ Intani-2 } & $10 \%$ & $34.6 \pm 1.15 \mathrm{ijk}$ & $16.6 \pm 1.02 \mathrm{gh}$ & $5.60 \pm 0.06$ & $13.69 \mathrm{o}$ \\
\hline & $12 \%$ & $36.0 \pm 1.20 \mathrm{jkl}$ & $18.0 \pm 1.00 \mathrm{hi}$ & $7.28 \pm 0.07$ & $15.66 \mathrm{p}$ \\
\hline & $14 \%$ & $38.8 \pm 1.00 \mathrm{~lm}$ & $19.2 \pm 0.88 \mathrm{i}$ & $11.20 \pm 0.06$ & $19.55 \mathrm{q}$ \\
\hline & $16 \%$ & $42.2 \pm 1.05 \mathrm{n}$ & $22.6 \pm 0.90 \mathrm{k}$ & $17.87 \pm 0.09$ & $24.99 \mathrm{r}$ \\
\hline
\end{tabular}

*The mean in the same column followed by the same letters are not significantly different $(\mathrm{p}<0.05)$

Table 2 also showed that the lowest mean number of eggs (147 eggs) was in the Membramo variety, at $10 \%$ initial moisture content, whereas the highest (548.33 eggs) was in Intani-2, at $16 \%$ initial moisture content. The lowest mean number of larvae (86.33 individuals) was in Membramo, at $10 \%$ initial moisture content, whereas the highest (398.33 individuals) was in Intani-2, at $16 \%$ initial moisture content. The lowest mean number of adults (15.33 individuals) was in Membramo, at $10 \%$ initial moisture content, whereas the highest (60.67 individuals) was in Intani-2, at $16 \%$ initial moisture content.

The statistical analysis of the median developmental time and susceptibility index of $R$. dominica showed a significant interaction effect (Table 3). Based on Table 3, it could be seen that the increasing initial moisture content of rice from $10 \%$ to $16 \%$ could reduce the median developmental time of $R$. dominica in the same rice varieties and increase susceptibility index. This showed that a decrease of median developmental time and an increase of susceptibility index was in line with an increase of the initial moisture content of rice. 
http://wjst.wu.ac.th

Table 2 Mean number of eggs, larvae, and F1 progeny of $R$. dominica in 6 rice varieties with different initial moisture contents in no-choice test experiment.

\begin{tabular}{lllll}
\hline Varieties & $\begin{array}{l}\text { Initial } \\
\text { moisture } \\
\text { content }\end{array}$ & Number of eggs & Number of larvae & $\begin{array}{l}\text { Number of F1 } \\
\text { progeny emerged }\end{array}$ \\
\hline IR-64 & $10 \%$ & $325.67 \pm 15.16 \mathrm{~cd}$ & $155.33 \pm 10.50 \mathrm{~cd}$ & $26.33 \pm 1.30 \mathrm{~d}$ \\
& $12 \%$ & $346.67 \pm 20.14 \mathrm{cde}$ & $166.67 \pm 8.67 \mathrm{de}$ & $30.67 \pm 0.47 \mathrm{gh}$ \\
& $14 \%$ & $365.33 \pm 18.18 \mathrm{def}$ & $212.67 \pm 5.38 \mathrm{f}$ & $36.67 \pm 0.54 \mathrm{l}$ \\
Ciherang & $16 \%$ & $369.33 \pm 20.15 \mathrm{def}$ & $242.33 \pm 10.85 \mathrm{~g}$ & $39.00 \pm 0.60 \mathrm{nop}$ \\
& $10 \%$ & $262.00 \pm 10.15 \mathrm{~b}$ & $148.33 \pm 9.35 \mathrm{c}$ & $27.00 \pm 0.25 \mathrm{de}$ \\
& $12 \%$ & $324.33 \pm 20.18 \mathrm{~cd}$ & $160.00 \pm 10.06 \mathrm{cde}$ & $29.00 \pm 0.48 \mathrm{fg}$ \\
Membramo & $14 \%$ & $343.00 \pm 24.16 \mathrm{cde}$ & $209.67 \pm 10.05 \mathrm{f}$ & $31.67 \pm 0.80 \mathrm{ij}$ \\
& $16 \%$ & $362.00 \pm 18.16 \mathrm{de}$ & $222.00 \pm 8.95 \mathrm{f}$ & $37.33 \pm 0.70 \mathrm{lmn}$ \\
& $10 \%$ & $147.00 \pm 10.25 \mathrm{a}$ & $86.33 \pm 7.50 \mathrm{a}$ & $15.33 \pm 0.25 \mathrm{a}$ \\
Cibogo & $12 \%$ & $176.00 \pm 15.15 \mathrm{a}$ & $91.67 \pm 9.25 \mathrm{a}$ & $18.00 \pm 0.50 \mathrm{~b}$ \\
& $14 \%$ & $257.33 \pm 15.35 \mathrm{~b}$ & $112.00 \pm 7.54 \mathrm{~b}$ & $24.00 \pm 1.25 \mathrm{c}$ \\
& $16 \%$ & $298.00 \pm 20.16 \mathrm{bc}$ & $156.00 \pm 8.53 \mathrm{~cd}$ & $28.33 \pm 0.30 \mathrm{ef}$ \\
& $10 \%$ & $353.00 \pm 17.18 \mathrm{de}$ & $175.67 \pm 5.78 \mathrm{e}$ & $31.33 \pm 0.45 \mathrm{i}$ \\
Sembada & $12 \%$ & $358.00 \pm 15.15 \mathrm{de}$ & $210.67 \pm 9.80 \mathrm{f}$ & $34.33 \pm 0.86 \mathrm{k}$ \\
& $14 \%$ & $370.00 \pm 18.16 \mathrm{def}$ & $227.67 \pm 8.50 \mathrm{f}$ & $38.67 \pm 0.75 \mathrm{mno}$ \\
& $16 \%$ & $416.33 \pm 20.18 \mathrm{fgh}$ & $247.67 \pm 6.78 \mathrm{~g}$ & $40.00 \pm 0.95 \mathrm{p}$ \\
& $10 \%$ & $357.67 \pm 16.10 \mathrm{de}$ & $211.00 \pm 8.65 \mathrm{f}$ & $31.00 \pm 0.30 \mathrm{hi}$ \\
& $12 \%$ & $365.00 \pm 14.85 \mathrm{def}$ & $220.67 \pm 7.50 \mathrm{f}$ & $37.00 \pm 0.65 \mathrm{~lm}$ \\
& $14 \%$ & $384.33 \pm 17.90 \mathrm{efg}$ & $247.33 \pm 7.05 \mathrm{~g}$ & $39.67 \pm 0.90 \mathrm{p}$ \\
& $16 \%$ & $441.67 \pm 10.52 \mathrm{hi}$ & $274.00 \pm 6.54 \mathrm{~h}$ & $41.33 \pm 0.85 \mathrm{p}$ \\
& $10 \%$ & $387.67 \pm 20.18 \mathrm{efg}$ & $282.67 \pm 8.53 \mathrm{~h}$ & $33.33 \pm 0.35 \mathrm{jk}$ \\
& $12 \%$ & $433.67 \pm 16.17 \mathrm{ghi}$ & $320.67 \pm 10.40 \mathrm{i}$ & $46.00 \pm 1.05 \mathrm{q}$ \\
& $14 \%$ & $478.00 \pm 10.24 \mathrm{i}$ & $358.00 \pm 8.95 \mathrm{j}$ & $51.00 \pm 1.18 \mathrm{r}$ \\
& $16 \%$ & $548.33 \pm 20.15 \mathrm{j}$ & $398.33 \pm 10.23 \mathrm{k}$ & $60.67 \pm 1.80 \mathrm{~s}$ \\
\hline \multirow{3}{*}{ Intani-2 } & & & &
\end{tabular}

*The mean in the same column followed by the same letters are not significantly different $(\mathrm{p}<0.05)$ 
http://wjst.wu.ac.th

Table 3 Mean of median developmental time of $R$. dominica, susceptibility index, and resistance category of 6 rice varieties with different initial moisture contents in no-choice test experiment.

\begin{tabular}{|c|c|c|c|c|}
\hline \multicolumn{2}{|c|}{ Treatment combination } & \multirow{2}{*}{$\begin{array}{l}\text { Median } \\
\text { developmental } \\
\text { time (Day) }\end{array}$} & \multirow[b]{2}{*}{ Susceptibility index } & \multirow[b]{2}{*}{ Resistance category } \\
\hline Varieties & $\begin{array}{l}\text { Moisture } \\
\text { content }\end{array}$ & & & \\
\hline IR-64 & $\begin{array}{l}10 \% \\
12 \% \\
14 \% \\
16 \%\end{array}$ & $\begin{array}{l}62.50 \pm 0.25 \mathrm{~g} \\
61.17 \pm 0.35 \mathrm{j} \\
58.50 \pm 0.30 \mathrm{i} \\
56.17 \pm 0.25 \mathrm{~h}\end{array}$ & $\begin{array}{l}5.23 \pm 0.03 \mathrm{gh} \\
5.60 \pm 0.05 \mathrm{~h} \\
6.16 \pm 0.04 \mathrm{i} \\
6.52 \pm 0.03 \mathrm{jk}\end{array}$ & $\begin{array}{l}\text { Moderately Resistant } \\
\text { Moderately Resistant } \\
\text { Moderately Resistant } \\
\text { Moderately Resistant }\end{array}$ \\
\hline Ciherang & $\begin{array}{l}10 \% \\
12 \% \\
14 \% \\
16 \%\end{array}$ & $\begin{array}{l}72.17 \pm 0.18 \mathrm{n} \\
70.83 \pm 0.35 \mathrm{~m} \\
69.50 \pm 0.201 \\
67.50 \pm 0.15 \mathrm{k}\end{array}$ & $\begin{array}{l}4.57 \pm 0.04 \mathrm{e} \\
4.75 \pm 0.02 \mathrm{ef} \\
4.97 \pm 0.03 \mathrm{fg} \\
5.36 \pm 0.05 \mathrm{~h}\end{array}$ & $\begin{array}{l}\text { Moderately Resistant } \\
\text { Moderately Resistant } \\
\text { Moderately Resistant } \\
\text { Moderately Resistant }\end{array}$ \\
\hline Membramo & $\begin{array}{l}10 \% \\
12 \% \\
14 \% \\
16 \%\end{array}$ & $\begin{array}{l}86.17 \pm 0.19 \mathrm{r} \\
85.17 \pm 0.20 \mathrm{q} \\
84.17 \pm 0.18 \mathrm{o} \\
82.83 \pm 0.25 \mathrm{o}\end{array}$ & $\begin{array}{l}3.17 \pm 0.03 \mathrm{a} \\
3.39 \pm 0.04 \mathrm{~b} \\
3.78 \pm 0.03 \mathrm{c} \\
4.04 \pm 0.05 \mathrm{~d}\end{array}$ & $\begin{array}{l}\text { Resistant } \\
\text { Resistant } \\
\text { Resistant } \\
\text { Moderately Resistant }\end{array}$ \\
\hline Cibogo & $\begin{array}{l}10 \% \\
12 \% \\
14 \% \\
16 \%\end{array}$ & $\begin{array}{l}53.83 \pm 0.75 \mathrm{~g} \\
49.50 \pm 0.42 \mathrm{f} \\
47.83 \pm 0.45 \mathrm{e} \\
47.17 \pm 0.50 \mathrm{e}\end{array}$ & $\begin{array}{l}6.40 \pm 0.04 \mathrm{ij} \\
7.15 \pm 0.05 \mathrm{l} \\
7.66 \pm 0.05 \mathrm{~m} \\
7.84 \pm 0.06 \mathrm{~m}\end{array}$ & $\begin{array}{l}\text { Moderately Resistant } \\
\text { Moderately Resistant } \\
\text { Moderately Resistant } \\
\text { Moderately Resistant }\end{array}$ \\
\hline Sembada & $\begin{array}{l}10 \% \\
12 \% \\
14 \% \\
16 \%\end{array}$ & $\begin{array}{l}50.50 \pm 0.45 \mathrm{f} \\
49.83 \pm 0.50 \mathrm{f} \\
47.17 \pm 0.45 \mathrm{e} \\
44.17 \pm 1.08 \mathrm{~d}\end{array}$ & $\begin{array}{l}6.80 \pm 0.04 \mathrm{k} \\
7.25 \pm 0.05 \mathrm{l} \\
7.81 \pm 0.05 \mathrm{~m} \\
8.43 \pm 0.06 \mathrm{n}\end{array}$ & $\begin{array}{l}\text { Moderately Resistant } \\
\text { Moderately Resistant } \\
\text { Moderately Resistant } \\
\text { Susceptible }\end{array}$ \\
\hline Intani-2 & $\begin{array}{l}10 \% \\
12 \% \\
14 \% \\
16 \%\end{array}$ & $\begin{array}{l}39.17 \pm 0.85 \mathrm{c} \\
37.83 \pm 0.50 \mathrm{bc} \\
36.83 \pm 0.35 \mathrm{~b} \\
33.50 \pm 0.53 \mathrm{a}\end{array}$ & $\begin{aligned} 8.96 & \pm 0.05 \mathrm{o} \\
10.12 & \pm 0.06 \mathrm{p} \\
11.18 & \pm 0.06 \mathrm{q} \\
12.26 & \pm 0.05 \mathrm{r}\end{aligned}$ & $\begin{array}{l}\text { Susceptible } \\
\text { Susceptible } \\
\text { Highly Susceptible } \\
\text { Highly Susceptible }\end{array}$ \\
\hline
\end{tabular}

*The mean in the same column followed by the same letters are not significantly different $(\mathrm{P}<0.05)$

Furthermore, it could be seen that the mean of the median developmental time of $R$. dominica in Intani-2 at $16 \%$ moisture content was the shortest (33.50 days), whereas the longest (86.17 days) was in Membramo at $10 \%$ initial moisture content. Based on the median developmental time variable, it was shown that $R$. dominica rapidly developed in Intani-2 at $16 \%$ moisture content, whereas the slowest was in Membramo at $10 \%$ moisture content. Based on median developmental time and F1 progeny variables, the susceptibility index of 6 rice varieties which were tested at 4 levels of moisture content could be calculated [13]. From both variables, it was shown that the lowest susceptibility index (3.17) was in Membramo at $10 \%$ initial moisture content, and the highest susceptibility index (12.26) was in Intani-2 at $16 \%$ initial moisture content.

Following the developed criteria by Dobie [14], the rice varieties tested in this study could be categorized into (a) resistant varieties, which consisted of Membramo at the initial moisture content of $\leq$ $14 \%$, (b) moderately resistant varieties, which consisted of Mebramo at the initial moisture content of 16 $\%$, IR-64, Ciherang, and Cibogo at the initial moisture content of $\leq 16 \%$, and Sembada at the initial moisture content of $\leq 14 \%$, (c) susceptible varieties, which consisted of Intani-2 at the initial moisture content of $\leq 12 \%$, and (d) highly susceptible, which consisted of Intani-2 at the initial moisture content of 
http://wjst.wu.ac.th

$\geq 14 \%$ (Table 3). Nonpreference mechanisms of grain are complex. They depend on the physicochemical and biochemical properties of grain, as well as the capacity of insects to adapt to the stored product conditions by biochemical and physical adaptation $[2,16]$. Developmental rate of $R$. dominica was fundamentally influenced by the physical and chemical contents of rice [17]. Chanbang et al. [18] stated that grain characteristics, including silica content, thickness of husk, relative hardness of grain kernel, phenolic, protein, and amylase contents, were associated with different responses of insects to stored products.

The results of the free-choice test for the number of adult insects present, the number of female adult insects present, and the percentage of weight loss showed that $R$. Dominica more preferred to the Intani-2 at $16 \%$ compared with the other rice varieties at different initial moisture contents tested. On the other hand, $R$. dominica less preferred to the Membramo variety at $10 \%$ initial moisture content. This could have happened because of the different physical characteristics and chemical contents of milled rice varieties [7]. Noris and Kogan [19] stated that plant defense against attacking insects uses its physical characteristics and chemical contents, such as phenolic compounds.

The no-choice test (Table 2) showed that the highest number of eggs (548.33), larvae (398.33), and F1 progeny (60.67) was in Intani-2 at $16 \%$ initial moisture content. On the other hand, the lowest number of eggs (147.00), larvae (86.33), and F1 progeny (15.33) was in Membramo at $10 \%$ initial moisture content. These results showed that the highest adult insect preference in rice varieties which was more susceptible was Intani-2 at $16 \%$ initial moisture content. On the other hand, Membramo at $10 \%$ initial moisture content was less preferred by $R$. dominica and it is categorized as the most resistant variety. Antunes et al. [20] and Perisic et al. [21] suggested that the insect population and weight loss of grain can be used as characteristics of insect preference to grain. Hence, based on the data presented in Table 2, it could be concluded that the Membramo variety was the most resistant variety, and Intani-2 was the most susceptible variety to $R$. dominica.

The rice susceptibility to $R$. dominica showed that the susceptibility on each variety changes with the increase of the initial moisture content (Table 3). Rice susceptibility will increase with the increase of the initial moisture content. The Membramo variety at the initial moisture content of $\leq 14 \%$ was categorized as resistant, while at the initial moisture content of $\geq 14 \%$ it was categorized as moderately resistant. Similarly, Sembada at initial moisture content of $\leq 14 \%$ was categorized as moderately resistant, while at the initial moisture content of $16 \%$ it was categorized as susceptible. Furthermore, Intani-2 with the initial moisture content of $\leq 12 \%$ was categorized as susceptible, while at the initial moisture content of $\geq 14 \%$ it was categorized as highly susceptible.

The regression analysis on the number of adult insects present, female adult insects present, and percentage of weight loss in the IR-64, Cibogo, Sembada, and Intani-2 varieties showed that there was a significantly different effect (Table 4). It also showed that the initial moisture content did not significantly affect the number of adult insects present, female insects present, or percentage of weight loss in the Membramo and Ciherang varieties. The number of adult insects present, the number of female adult insects present, and percentage of weight loss increases with the increasing of initial moisture content. The highest effect of the initial moisture content was in the Intani-2 variety, and the lowest was in the Membramo variety.

The relationship between the initial moisture content of rice and the hardness level of rice, phenol, and ash content in each variety showed that the increase of the initial moisture content tends to decrease the hardness of rice (Table 5). On the other hand, the effect of the initial moisture content on the phenol and ash content in all varieties of rice was not significant. The highest hardness effect on the initial moisture content appeared in the Intani-2 variety $(b=-22.37)$ and the lowest effect was in the Membramo variety $(b=-6.44)$. The increase in rice moisture content caused a decrease in the hardness of rice. Conversely, if the moisture level is low, then the hardness of rice is increased. 
http://wjst.wu.ac.th

Table 4 Regression (b) and correlation (r) coefficients between the initial moisture content and the number of adult insects present, number of female adult insects present of $R$. dominica, and the percentage of weight loss of rice.

\begin{tabular}{lllllll}
\hline Varieties & \multicolumn{2}{c}{$\begin{array}{c}\text { Number of adult } \\
\text { insects present }\end{array}$} & \multicolumn{2}{c}{$\begin{array}{c}\text { Number of female } \\
\text { adult insects present }\end{array}$} & $\begin{array}{c}\text { Percentage of } \\
\text { weight loss } \\
(\%)\end{array}$ \\
\cline { 2 - 7 } & b & r & b & R & b & r \\
\hline IR-64 & $1.40^{*}$ & 0.90 & $1.04 *$ & 0.82 & $0.17 *$ & 0.90 \\
Ciherang & $1.25 \mathrm{NS}$ & 0.85 & $0.72 \mathrm{NS}$ & 0.82 & $0.13 \mathrm{NS}$ & 0.84 \\
Membramo & $1.10 \mathrm{NS}$ & 0.49 & $0.61 \mathrm{NS}$ & 0.33 & $0.04 \mathrm{NS}$ & 0.52 \\
Cibogo & $2.48^{*}$ & 0.96 & $1.29 *$ & 0.94 & $0.24 *$ & 0.87 \\
Sembada & $2.55^{*}$ & 0.97 & $1.42^{*}$ & 0.94 & $0.69 *$ & 0.94 \\
Intani-2 & $2.72^{*}$ & 0.97 & $1.65^{*}$ & 0.96 & $2.04 *$ & 0.96 \\
\hline
\end{tabular}

*= Significant at $(\mathrm{p}<0.05), \mathrm{NS}=$ non significant $(\mathrm{p}>0.05)$

Table 5 Regression (b) and correlation (r) coefficients between the initial moisture content and the hardness and phenol content in each rice variety.

\begin{tabular}{llllllc}
\hline \multirow{2}{*}{ Varieties } & \multicolumn{2}{c}{ Hardness } & \multicolumn{2}{c}{ Phenol } & \multicolumn{2}{c}{ Ash } \\
\cline { 2 - 7 } & $\mathbf{b}$ & $\mathbf{r}$ & $\mathbf{b}$ & $\mathbf{R}$ & $\mathbf{b}$ & $\mathbf{r}$ \\
\hline IR-64 & $-10.72^{* *}$ & -0.85 & $-0.14 \mathrm{NS}$ & -0.07 & $-0.05 \mathrm{NS}$ & -0.06 \\
Ciherang & $-8.53^{* *}$ & -0.81 & $-0.01 \mathrm{NS}$ & -0.02 & $-0.10 \mathrm{NS}$ & -0.03 \\
Membramo & $-6.44^{*}$ & -0.81 & $-0.02 \mathrm{NS}$ & -0.02 & $-0.12 \mathrm{NS}$ & -0.03 \\
Cibogo & $-16.35^{*}$ & -0.86 & $0.13 \mathrm{NS}$ & 0.05 & $0.14 \mathrm{NS}$ & 0.07 \\
Sembada & $-11.59^{* *}$ & -0.86 & $0.14 \mathrm{NS}$ & 0.07 & $0.16 \mathrm{NS}$ & 0.08 \\
Intani-2 & $-22.37^{*}$ & -6.92 & $0.08 \mathrm{NS}$ & 0.06 & $0.15 \mathrm{NS}$ & 0.015 \\
\hline
\end{tabular}

$*=$ Significant at $(\mathrm{p}<0.05), \mathrm{NS}=$ non significant $(\mathrm{p}>0.05)$

In the experiments using the free-choice and the no-choice tests, it was shown that the highest preference was in Intani-2 at $16 \%$ initial moisture content, because it had the lowest phenol content, lowest grain hardness, and highest ash content. On the other hand, the lowest preference was in Membramo at $10 \%$ initial moisture content, because it had the highest hardness level, phenol content, and lowest ash content.

To assess the above results, Astuti et al. [7] calculated the correlation coefficient between ash, phenol, and rice grain hardness with the number of eggs, the number of F1 progeny of $R$. dominica emerged, the median developmental time, and the susceptibility index. Furthermore, Astuti et al. [7] showed that ash content has a positive correlation with the number of eggs, F1 progeny of $R$. dominica emerged, and the susceptibility index. On the other hand, ash content had a negative correlation with median developmental time. Nation et al. [22] and Parra et al. [23] said that ash content in rice contained a few kinds of minerals, including $\mathrm{Fe}$, which has an important role in some biological processes, such as enzymatic reaction, ecdysis hormone production, cuticle growth, and other metabolic processes. Furthermore, Astuti et al. [7] showed that phenol content and rice grain hardness have a negative correlation with the number of eggs, F1 progeny emerged, and rice susceptibility, while the phenol content and grain hardness have a positive correlation with the median developmental time. These 
http://wjst.wu.ac.th

results show that higher phenol content and rice grain hardness will decrease the number of eggs and F1 progeny emerged, as well as rice grain susceptibility.

The combination of factors between grain hardness and nutritional value have influenced the resistance of rice varieties against $S$. oryzae [20,24]. The varieties which have low ash content could increase phenol concentration but reduce amylase concentration. This condition make the varieties more resistant to $S$. cerealella $[25,26]$. McGaughey et al. [17] examined the reproduction of $S$. oryzae and $R$. dominica on several wheat classes and concluded that kernel hardness significantly affected $S$. oryzae reproduction, while $R$. dominica was not affected. A wide range of differences in kernel hardness caused different results. The resistance of each wheat classes was correlated with the physical and chemical properties. Insect development preferred both harder seed and lower starch content less.

Resistant varieties show that physical and biochemical characteristics can change the behavior response (nonpreference) or impact poorly on the pest development and the ability to survive of the through metabolism deviation [27]. Noris and Kogan [19] stated that plant resistance mechanisms against pests can be through by physical and chemical properties, such as phenolic content as a secondary metabolism. Especially, phenolic acid and ferulic acid on rice could act as antifeedants [27,28]. Perisic et al. [21] stated that the developmental rate of $R$. dominica on grain was significantly influenced by physical and chemical properties. Keskin \& Ozkaya [29] stated that grain hardness was one of the factors that determine the infestation of $R$. dominica. Katz et al. [30] stated that the hardness of hard wheat decreases with the increasing of moisture content. The hardness kernel of soft wheat was not significantly changed in up to $13 \%$ moisture content, but it showed a rapid decrease in hardness when the moisture content was $13 \%$ over.

Moisture content affects dry matter losses, quality of the grain, and biochemical reactions of cereal grain in storage [31,32]. Maize with high moisture content will deteriorate quickly and is usually facilitated by insect infestation [33]. Insects in grain also prefer these conditions. Manu et al. [34] said that the role of initial grain moisture content could make stored products safe. The level of grain moisture content of $13 \%$ over could encourage the growth of microorganisms and the activity of grain insect pests. In addition, insect infestation is greatly developed at $10-15 \%$ of grain moisture content with favorable temperature. However, insect development will be inhibited with low moisture content. This is in line with the results of the population of $T$. castaneum being reduced with low moisture content of wheat grain.

From these results, it can be said that the different preference level of rice varieties is predictable because of the differences in the hardness level, phenol, and ash contents of each rice varieties at different kinds of moisture content. This resistance of grain is correlated with the physical and chemical properties: phenol, ash, and hardness level of grain. Varieties of rice with the lowest ash content, highest phenol content, and lowest hardness are not attractive for insect species development.

Intani-2 at $16 \%$ initial moisture content can be considered as great nutrition for $R$. dominica development and it is also the most susceptible to attack, as Intani-2 has the highest grain moisture content, the lowest phenolic content, and the lowest hardness levels. On the other hand, Membramo at $\leq 14 \%$ can be considered as a variety resistant to $R$. dominica, as Membramo has the highest phenol and lowest ash content from the rice varieties tested. Furthermore, one of the physical characteristics, the hardness of rice, showed that Membramo had the highest level of hardness compared to other rice varieties. The rice hardness level were also caused by the level of the initial moisture content of rice. The increase of initial moisture content in rice causes a decrease in hardness level. On the other hand, the increase of initial moisture content in rice does not significantly affect the phenol and ash content.

\section{Conclusions}

It is concluded that $R$. dominica more preferred to the Intani-2 variety at $16 \%$ initial moisture content, and less preferred to the Membramo variety at $10 \%$ initial moisture content less. The same results from the no-choice test revealed that Intani- 2 at $\geq 14 \%$ initial moisture content is categorized as a highly susceptible variety. On the other hand, the Membramo variety at $\leq 14 \%$ is considered as a 
http://wjst.wu.ac.th

resistant variety. The preference to the rice varieties and susceptibility level of rice is affected by the hardness level, ash content, and phenol content of grain. The rice hardness level is caused by the level of initial moisture content of rice. However, the chemical characteristics of rice are not affected by the level of initial moisture content.

\section{Acknowledgment}

We thank Anak Agung Aryawan for helping the research process and Department of Plant Pests and Diseases, Faculty of Agriculture, University of Brawijaya, for facilitating the research.

\section{Reference}

[1] D Rees. Insects of Stored Products. CSIRO Publishing, Australia, 2004, p. 181.

[2] CM Smith. Plant Resistance to Insects: A Fundamental Approach. John Wiley \& Sons, 1989, p. 286.

[3] P Sittusuang and O Imura. Damage of rough and brown rice by four stored-product insect species. Appl. Ent. Zool. 1987; 22, 585-93.

[4] PA Edde. A review of the biology and control of Rhyzopertha dominica (F.) the lesser grain borer. J. Stored Prod. Res. 2012; 48: 1-18.

[5] CP Haines. Grain Storage in the Tropics. In: DG Jayas, NDG White and WE Muir (Eds.). StoredGrain Ecosystem. Marcel Dekker, New York, Basel, Hong Kong, 1995, p. 55-99.

[6] LP Astuti. Oviposition and feeding preferences of Rhyzopertha dominica (F.) (Coleoptera: Bostrichidae) on six rice varieties in postharvest storage. In: Proceedings of the International Seminar on Natural Resourches, Climate Change and Food Security in Developing Countries, Surabaya, Indonesia, 2011.

[7] LP Astuti, G Mudjiono, S Rasminah Ch and BT Rahardjo. Susceptibility of milled rice varieties to the lesser grain borer Rhyzopertha dominica (F.). J. Agric. Sci. 2013; 2, 145-9.

[8] LP Astuti, G Mudjiono, S Rasminah Ch, BT Rahardjo. Influence of temperature and humidity on the population growth of Rhyzopertha dominica (F.) (Coleoptera: Bostrichidae) on milled rice. $J$. Entomol. 2013; 10, 86-94.

[9] KC Kumawat. Effect of abiotic factors on biology of Rhyzopertha dominica (Fab.) on wheat. Ann. Pl. Protec. Sci. 2007; 15, 111-5.

[10] MR Speight, MD Hunter and AD Watt. Ecology of Insect: Concepts and Aplications. $2^{\text {nd }}$ ed. Blackwell, Maiden, 2009, p. 628.

[11] AW Sousa, LRD Faroni, F Rezende, MAG Pimentel and GN Silva. Population growth of Cathartus quadricollis (Guerin-Meneville) (Coleoptera: Silvanidae) in products stored at different temperatures. African J. Food Sci. 2009; 3, 347-51.

[12] DW Hagstrum, PW Flinn, RW Howard. Ecology. In: B Subramanyam and DW Hagstrum (Eds.). Integrated Management of Insects in Stored Products. Marcel Dekker, New York, Basel. Hongkong, 1996, p. 71-134

[13] P Dobie and AM Kilminster. The susceptibility of triticale to post-harvest infestation by Sitophilus zeamais Motschulsky, Sitophilus oryzae (L.) and Sitophilus granarius (L.). J. Stored Prod. Res. 1977; 14, 87-93.

[14] P Dobie. The laboratory assessment of the inherent susceptibility of maize varieties to post harvest infestation by Sitophilus zeamais Motsch. (Coleoptera: Curculionidae). J. Stored Prod. Res. 1974; 10, 183-97.

[15] RGD Steel and JG Torrie. Principles and Procedures of Statistics. McGraw Hill Book, New York, 1980, p. 672.

[16] J Narow, JR Warchalewski, D Piasecka-Kwiatkowska, A Niewiada, M Gawlak, ST Grundas and J Fornal. The effect of some biochemical and technological properties of wheat grain on granary weevil (Sitophilus granarius L.) (Coleoptera: Curculionidae) development. In: Proceedings of the $9^{\text {th }}$ International Working Conference on Stored Product Protection. 2006, p. 400-7. 
http://wjst.wu.ac.th

[17] WH McGaughey, RD Speirs and CR Martin. Susceptibility of classes of wheat grown in the United Stated to the stored-grain insects. J. Econ. Entomol. 1990; 83, 1122-7.

[18] Y Chanbang, FH Arthur, GE Wilde and JE Trone. Hull characteristics as related to susceptibility of different varieties of rough rice to Rhyzopertha dominica (F.) (Coleoptera: Bostrichidae). J. Stored Prod. Res. 2008; 44, 205-12.

[19] DM Noris and M Kogan. Biochemical and Morphological Basis of Resistance. In: FG Maxwell and PR Jennings (Eds.). Breeding Plant Resistant to Insects. Wiley \& Sons, United Stated of America, 1980, p. 23-61.

[20] C Antunes, R Mendes, A Lima, G Barros, P Fields, LB Da Costa, JC Rodriques, MJ Silva, AM Correia and MO Carvalho. Resistance of rice varieties to the stored-product insect, Sitophilus zeamais (coleoptera: Curculionidae). J. Entomol. 2015; 109, 445-3.

[21] V Perisic, FN Vukajlovic, DZ Predojevic, K Lukovic, V Prisic, S Pesic and V Rajicic. Feeding preferences and progeny production of Rhyzopertha dominica (Fabricius 1792) (Coleoptera: Bostrichidae) in small grains. Serbia. Biol. Nyssana 2018; 9, 55-61.

[22] JL Nation. Insect Physiology and Biochemistry. CRC Press, 2008, p. 544.

[23] JRP Parra. The Evolution of Artificial Diets and Their Interactions in Science and Technology. In: AR Panizzi and JRP Parra (Eds.). Insect Bioecology and Nutrition for Integrated Pest Management. CRC Press. Taylor \& Francis Group, 2012, p. 51-92.

[24] RR Cogburn. Domestic rice varieties: Apparent resistance to rice weevil, lesser grain borer and angoumois grain moth. Environ. Entomol. 1974; 3, 681-5.

[25] M Akhter, S Sultana, T Akter and S Begum. Oviposition preference and development of rice weevil, Sitophiluss oryzae (LIN.) (coleoptera: Curculionidae) in different stored grains. Bangladesh J. Zool. 2017; 45, 131-8.

[26] N Din, A Misbah, H Shahbaz, I Zafar and H Dilbar. Feeding preference and biology of Tribolium castaneum herbst (Coleoptera: Tenebrionidae) in different wheat varieties. J. Entomol. Zool. Stud. $2018 ; 6,147-50$.

[27] ZK Zhou, S Robards, C Helliwell and Blanchard. The distribution of phenolic acid in rice. Food Chem. 2003; 87, 401-6.

[28] FE Soetaredjo, S Ismadji and YH Ju. Phenolic Compounds in Staple Plants. In: S Munne-Bosch (Ed.). Phenolic Acids. Composition, Applications and Health Benefits. Nova Science Publishers, New York, 2012, p. 15-31.

[29] S Keskin and H Ozkaya. Effect of storage and insect infestation on the mineral and vitamin contents of wheat grain and flour. J. Econ. Entomol. 2013; 106, 1058-63.

[30] R Katz, ND Collins and AB Cardwell. Hardness and moisture content of wheat kernels. Cereal Chem. 1961; 38, 364-8.

[31] HB Gonzales, PR Armstrong, RG Maghirang. Simultaneous monitoring of stored grain with relative humidity, temperature, and carbon dioxide sensors. Appl. Eng. Agric. 2009; 25, 595-604.

[32] J Lawrence and DF Maier. Aeration strategy simulation for wheat storage in the subtropical region of North India. Trans. ASABE 2011; 54, 1395-405.

[33] RA Suleiman, KA Rosentrater and CJ Bern. Effects of Deterioration Parameters on Storage of Maize: An ASABE Meeting Presentation. Kansas City, Missouri, USA, 2013, 131593351.

[34] N Manu, GP Opit, EA Osekre, FH Arthur, G Mbata, P Armstrong, JK Danso, SG McNeill and JF Campbell. Moisture content, insect pest infestation and mycotoxin levels of maize in markets in the northern region of Ghana. J. Stored Prod. Res. 2018; 80, 10-20. 